pressure tester mark II, does not include any functional testing of compression hosiery. ${ }^{14}$

We found only a few stockings to be effective. The criteria for satisfactory stockings are important for venous function-namely, they should show a significant linear trend with site of measurement, no systematic difference between sizes, and no interaction between size and site. These criteria were applied only within the manufacturers' size specifications. Only five of the 15 types of stocking tested reached the fairly basic standards we had set. In the second part of the study all six stockings tested (with the exception of Softgrip) significantly improved venous refilling time in patients with both superficial and deep vein incompetence. Refilling time more nearly approached normal values, however, when the stocking met our criteria for being satisfactory, particularly in patients with deep vein incompetence.

In practice, patients' acceptance of compression hosiery is better when the stockings are selected from those shown to have appropriate linear graduation. Functional testing should be an integral part of any future British Standards specification. This would lead to a more satisfactory prescribing policy in both hospitals and the community and to a greater benefit to patients.

We thank Mrs Claire Llewellyn Williams, formerly blood flow technician at this hospital, for her help and Mrs P A Jones for secretarial help.

\section{References}

1 Davison AW. Derby, its rise and progress. Wakefield: Short Run Publishers Ltd, 1970:265-7.

2 Horner J, Fernandes J, Fernandes E, $e t$ al. Value of graduated compression stockings in deep venous insufficiency. $\mathrm{Br} \mathrm{Med}$ f 1980;280:820-1.

3 Jones NAG, Webb PJ, Rees RI, et al. A physiological study of elastic compression stockings in venous disorders of the leg. Brf Surg 1980;67:569-72.

4 Partsch H. Do we need firm compression stockings exerting high pressure? Vasa 1984;13:52-7.

5 Norris CS, Turley G, Barnes RW. Noninvasive quantification of ambulatory venous hemodynamics during elastic compressive therapy. Angiology fournal of Vascular Diseases 1984;35:

6 Holford CP. Graded compression for preventing deep vein thrombosis. $\mathrm{Br} M$ ed $\mathcal{f}$ 1976;ii:969-70.

7 Sigel B, Edelstein AL, Felix WR, et al. Compression of the deep venous system of the lower leg during inactive recumbency. Arch Surg 1973;106:38-43.

8 Horner J, Lowth LC, Nicolaides AN. A pressure profile for elastic stockings. Br Med $\mathcal{J}$ 1980;280:818-20.

9 Van den Berg E, Borgnis FE, Bollinger AA, et al. A new method for measuring the effective compression of medical stockings. Vasa 1982;11:117.

10 Abramowitz HB, Queral LA, Flinn WR, et al. The use of photoplethysmography in the assessment of venous insufficiency. A comparison to venous pressure measurement. Vascular Surgery 1979;86:434-41.

11 Miles CR, Nicolaides AN. Photoplethysmography, principles and development. In: Nicolaides AN, Yao J, eds. Investigations of vascular disorders. London: Pitman, 1981:501-5.

12 Nicolaides AN, Kakkar VV, Field ES, et al. The origin of deep venous thrombosis: a venographic study. Br f Radiol 1971;44:53-4.

13 Reddy PJ, Lamont P, Downes S, et al. An objective assessment of compression hosiery in deep venous insufficiency. Archives of the $14 \mathrm{th}$ World Congress of the International Union of Angiology venous insurfici

14 British Standards Institution. British standards specification for graduated compression hosiery. London: British Standards Institution, 1985. (BS 6612.)

\title{
Quantitative DNA analysis of low grade cervical intraepithelial neoplasia and human papillomavirus infection by static and flow cytometry
}

\author{
K C WATTS, O A N HUSAIN, M J CAMPION, FRANCESCA LORRIMAN, \\ E BLANCHE BUTLER, D MCCANCE, D JENKINS, A SINGER
}

\begin{abstract}
Quantitative deoxyribonucleic acid (DNA) analysis of cervical biopsy specimens from 26 women with cytological, colposcopic, and histological evidence of mild cervical atypia consistent with cervical intraepithelial neoplasia grade I, reactive atypia, or human papillomavirus infection alone or in combination was performed in a comparative evaluation of Feulgen microspectro-
\end{abstract}

Department of Cytopathology, Charing Cross Hospital, London W6 8RF

K C WATTS, CMIAC, senior scientist

O A N HUSAIN, FRCPATH, FRCOG, consultant pathologist

FRANCESCA LORRIMAN, PHD, biochemist

Royal Northern Hospital, London

$M$ J CAMPION, MB, research fellow in gynaecological oncology

A SINGER, DPHIL, FRCOG, consultant gynaecologist

Elizabeth Garrett Anderson Hospital, London

E BLANCHE BUTLER, FRCOG, FRCPATH, director, early diagnostic unit

Department of Microbiology, United Medical and Dental Schools of Guy's and St Thomas's Hospitals, London

D MCCANCE, PHD, senior lecturer

Whittington Hospital, London

D JENKINS, MRCPATH, consultant pathologist

Correspondence to: Mr Watts. photometry, the fast interval processor image analysis system, and flow cytometry. The fast interval processor image analysis system showed a distinct advantage over the other methods, being faster and allowing the operator to see the cells that were selected for measurement. The three methods of measurement together showed that the DNA content of at least $2 \%$ of the cells measured exceeded $5 \mathrm{C}(\mathrm{C}$ being the haploid amount of DNA in a normal cell and $2 \mathrm{C}$ representing the diploid complement of a normal cell) in all cases of cervical intraepithelial neoplasia grade $I$ and reactive atypia and in $87 \%$ of those reported as showing human papillomavirus infection alone. In contrast, the DNA content of cervical biopsy specimens from the transformation zone of 11 normal controls did not exceed 4C.

This study shows the value of using a DNA threshold-that is, the "5C exceeding rate"-to distinguish between normal and neoplastic appearances of the cervix. These results support the view that cervical infection by human papillomavirus is a true precursor of neoplasia.

\section{Introduction}

Recent developments in techniques of quantitative deoxyribonucleic acid (DNA) analysis by flow and static cytometry have renewed interest in the use of ploidy analysis and morphometry in diagnosis and the evaluation of tumour behaviour, prognosis, and response to chemotherapy. ${ }^{1}$

Many invasive intraepithelial neoplasms are associated with an aneuploid nuclear DNA content. The aneuploid nature and 
malignant potential of cervical intraepithelial neoplasm grade III is well established, $30 \%$ of cases progressing to invasive cancer. ${ }^{2-4} \mathrm{The}$ DNA content of cervical intraepithelial neoplasia grade I, however, has not been accurately defined. A flow cytometric study of cervical biopsy specimens did not show any evidence of aneuploidy in cases reported as cervical intraepithelial neoplasia grade I on histological examination, ${ }^{5}$. and microspectrophotometric studies of cervical intraepithelial neoplasia grade I and human papillomavirus infection of the cervix did not report aneuploidy. ${ }^{6}$ Until recently subclinical cervical infection with human papillovirus has been thought likely to regress spontaneously and to be associated with a polyploid nuclear DNA content. ${ }^{6}$

The apparent absence of aneuploidy in low grade cervical intraepithelial neoplasia or human papillovirus infection, or both, does not accord with the results of a recent prospective study that showed that mild cervical atypia may be progressive.? This may reflect the insensitivity both of the instrument used to measure the DNA content and of the criteria adopted to determine the presence of aneuploid cells.

Many workers using quantitative analyses of DNA have attempted to express their results as a DNA index, and they have proposed a DNA value for the stem cell. The DNA index is the ratio of the DNA content of the nuclei of tumour tissue compared with the DNA content of normal (diploid) cells phases $G_{0}$ and $G_{1}$. A diploid tumour would, therefore, have a DNA index of $1 \cdot 0$. This procedure is subjective, and multiple modal distributions indicating heterogenous DNA values are commonly identified. Furthermore, in specimens in which the proportion of neoplastic epithelium is small, as in cervical intraepithelial neoplasia, the number of neoplastic cells is often so small that a second aneuploid peak cannot be discerned. The problems of this analysis of so called "rare event" neoplastic cells can be overcome by using the more objective criteria first described by Ploem-Zaaijer et al and known as the " $5 \mathrm{C}$ exceeding rate." "In this method the proportion of cells with a DNA content of greater than $5 \mathrm{C}$ is determined and expressed as a percentage of the total number of cells measured ( $2 \mathrm{C}$ being the normal chromosome complement of diploid cells).

The aim of this study was to characterise the DNA content of cases reported histologically as cervical intraepithelial neoplasia grade I, reactive atypia, or human papillomavirus infection by using three methods of DNA measurement and an objective criterion for aneuploidy-namely, the $5 \mathrm{C}$ exceeding rate.

\section{Patients and methods}

\section{STUDY GROUP}

Twenty six women were selected at random from women whose cervical smears showed human papillovirus infection alone or mild dyskaryosis with or without evidence of human papillovirus infection..$^{9} \mathrm{~A}$ biopsy specimen was taken from the atypical transformation zone of the cervix of each patient under colposcopic vision with Eppendorf biopsy forceps and sent for routine histopathological examination. Informed consent was obtained for biopsy specimens to be taken from the cervical transformation zone of 11 control patients at the same time as they were being examined for other gynaecological symptoms; these women had no cytological or colposcopic evidence of cervical atypia.

\section{HISTOPATHOLOGY}

A section $30 \mu \mathrm{m}$ thick adjacent to a section $4 \mu \mathrm{m}$ thick that had been cut for routine histopathological examination was disaggregated into two aliquots for flow and static cytometry. ${ }^{10}$ The histopathological appearances were reported from a section $4 \mu \mathrm{m}$ thick stained with haemotoxylin and eosin by a panel of gynaecological pathologists, who used the criteria for cervical intraepithelial neoplasia, reactive atypia, and human papillovirus infection. ${ }^{9}$ The histological diagnosis was reported as human papillovirus infection, reactive atypia, or cervical intraepithelial neoplasia grade I with or without evidence of human papillovirus infection. All sections in this study contained an appreciable proportion of normal stromal or epithelial cells, or both.

\section{C EXCEEDING RATE}

The $5 \mathrm{C}$ exceeding rate is an objective assessment of the proportion of cells with a DNA content greater than $5 \mathrm{C}$; $\mathrm{C}$ is the haploid amount of DNA in a normal cell and $2 \mathrm{C}$ represents the diploid chromosome complement of a normal cell. Cells with a DNA content equivalent to $8 \mathrm{C}$ or $16 \mathrm{C}$ were excluded to avoid misclassification of polyploidy.

\section{FLOW CYTOMETRY}

An aliquot of the cell deposit (approximately $0.1 \mathrm{ml}$ ) of the disaggregated section was resuspended in $2 \mathrm{ml}$ of ribonuclease A (Sigma Chemical Co) $1 \mathrm{mg} / \mathrm{ml}$ at $20^{\circ} \mathrm{C}$, washed in phosphate buffered saline $\mathrm{pH} 7 \cdot 4$, then stained with propidium iodide $6.9 \times 10^{-5} \mathrm{M}$ in $3.8 \times 10^{-2} \mathrm{M}$ sodium citrate (Sigma Chemical $\mathrm{Co}$ ) for 30 minutes at room temperature and analysed with a Coulter EPICS C Flow Cytometer at an excitation wavelength of $488 \mathrm{~nm}$. Debris and cell aggregates were gated out by forward angle light scatter. The fluorescence emission of 5000 events within the gate settings at $600 \mathrm{~nm}$ were recorded on a linear scale.

Additional sections of cervix $30 \mu \mathrm{m}$ thick were disaggregated to provide samples for setting up the machine. The optimal positions of the gates on forward light scatter were determined by running, sorting and collecting cells of more than 5C. The collected cell suspension was concentrated, smeared on to a glass slide, and viewed under a fluorescence microscope to confirm the absence of cell doublets or aggregates. We were unable to determine the proportions of stromal and epithelial cells by using forward angle light scatter. We used chicken erythrocytes and human peripheral blood monocytes as internal standards, but they failed to give a consistent ratio when compared with the diploid $G_{1}$ peak of the disaggregated section. This problem has been reported by other workers, and it is now accepted practice to rely on the presence of normal diploid cells within the section under study to determine the position of the $2 \mathrm{C}$ peak. From the position of the $2 \mathrm{C}$ peak the percentage of cells exceeding $5 \mathrm{C}$ was calculated.

\section{PREPARATION AND STAINING OF MONOLAYERS FOR STATIC CYTOMETRY}

Monolayers were prepared from the second aliquot of the disaggregated section, using slides coated with poly-L-lysine. ${ }^{11}$ The optimal hydrolysis time for normal cervical tissues that had been disaggregated, fixed in formalin, and embedded in paraffin wax was found to be 30 minutes. All abnormal slides were then stained by the Feulgen nucleal reaction with a hydrolysis time of 30 minutes.

\section{MICROSPECTROPHOTOMETRY}

The relative absorbance of a minimum of 50 epithelial nuclei was measured for each normal specimen with a Vickers M85 scanning and integrating microdensitometer at a wavelength of $545 \mathrm{~nm}$, a magnification of 40 , and a scanning spot size of $0.5 \mu \mathrm{m}$. These results were plotted as DNA frequency histogams with arbitrary units of relative absorbence for each nucleus to establish the modal absorbance value equivalent to $2 \mathrm{C}$. A further 50 cytologically abnormal epithelial nuclei were selected and measured for each abnormal specimen. The proportion of cells exceeding the $5 \mathrm{C}$ threshold was calculated.

\section{FAST INTERVAL PROCESSOR IMAGE ANALYSIS}

Fast interval processor image anaiysis was developed by the pattern recognition section of the Medical Research Council Clinical and Population Cytogenetics Unit, Edinburgh, for automated metaphase finding and automated cervical cancer screening, but it can also be used as a microdensitometer..$^{12}$ Image sensing is by a linear array diode, and the machine differentiates points of interest from the background by delineating measurements of light intensity at each point of a sampling grid of $1.0 \times 0.6$ $\mu \mathrm{m}$. Connected objects are examined and measurements made of their area and their integrated optical density. To avoid the measurement of "doublets" or overlapping nuclei the machine was used in a semiautomated scan frame mode. An average of 50 epithelial nuclei were measured for each normal control and pooled to establish the modal value equivalent to $2 \mathrm{C}$. A mean of 93 (range 58-200) cytologically abnormal nuclei were then selected and measured for each abnormal specimen. The number of cells exceeding $5 \mathrm{C}$, excluding $8 \mathrm{C}$ and $16 \mathrm{C}$, was calculated and expressed as a percentage of the total number of nuclei measured. 
Number of specimens showing at least $2 \%$ of cells exceeding $5 C$ by each method of measurement $(n=26)$

\begin{tabular}{|c|c|c|c|c|}
\hline Histological diagnosis & Microspectrophotometry & $\begin{array}{c}\text { Fast interval } \\
\text { processor }\end{array}$ & $\begin{array}{c}\text { Flow } \\
\text { cytometry }\end{array}$ & $\begin{array}{c}\text { No (\%) } \\
\text { aneuploid }\end{array}$ \\
\hline $\begin{array}{l}\text { Cervical intraepithelial neoplasia grade } I \text { alone }(n=1) \\
\text { Cervical intraepithelial neoplasia grade } I \text { and human papillomavirus infection }(n=4) \\
\text { Reactive atypia and human papillomavirus infection }(n=6) \\
\text { Human papillomavirus infection alone }(n=15)\end{array}$ & $\begin{array}{l}0 \\
1 \\
5 \\
7\end{array}$ & $\begin{array}{r}0 \\
2 \\
3 \\
13\end{array}$ & $\begin{array}{l}1 \\
3 \\
3 \\
7\end{array}$ & $\begin{array}{r}1(100) \\
4(100) \\
6(100) \\
13(87) \\
\end{array}$ \\
\hline Total & 13 & 18 & 14 & $24(92)$ \\
\hline
\end{tabular}

\section{Results}

Populations of tetraploid cells were found in all 11 normal controls, but cells greater than $5 \mathrm{C}$ were not seen with any of the three methods of measurement. The table shows the number of cases with at least $2 \%$ of cells greater than $5 \mathrm{C}$.

An aneuploid distribution of DNA was found in $69 \%$ of slides measured by the fast interval processor, $50 \%$ measured by microspectrophotometry, and $54 \%$ measured by flow cytometry. On testing the null hypothesis with the $\chi^{2}$ test there were no significant differences in the detected percentages of cells of greater than $5 C$ between any pair of machines ( $p>0.05$ in all cases).

\section{Discussion}

Although the apparent differences in sensitivity between the methods of measurement were not significant, there are practical advantages to each method. The fast interval processor system can measure the optical density of a field of objects simultaneously, whereas for the microspectrophotometer each object must be selected and positioned in the mask; this is time consuming. DNA measurement by flow cytometry can be done rapidly, and in this study the average time to acquire 5000 events was three minutes. There is, however, a problem with flow analysis in controlling the proportion of neoplastic and normal stromal cells in the sample. Although some normal cells are required as a $2 \mathrm{C}$ reference, an excess will mask the presence of cells with high contents of DNA, leading to false negative results. Cell suspensions can be enriched with neoplastic cells by dissecting out the area of interest, but this technique is suitable only for larger tissue blocks and cannot be done on colposcopic biopsy specimens.

By assessing the results of all three methods of measurement we determined aneuploidy in all cases of cervical intraepithelial neoplasm grade I and reactive atypia and in $87 \%$ of biopsy specimens reported as human papillomavirus infection. The increased DNA content of cells infected with human papillomavirus is most unlikely to be due to the presence of viral DNA. Even if the infected cell contained $10 \times 10^{6}$ copies of a human papillomavirus genome the amount of DNA would still be less than the DNA content of the diploid human genome.

Our results differ from those of Hughes $e t$ al, who reported aneuploidy in only two of $11(18 \%)$ cases of koilocytotic atypia and in two of $14(14 \%)$ cases reported as cervical intraepithelial neoplasia grade $\mathrm{I} .{ }^{13}$ Their criterion for aneuploidy and the fact that they used flow cytometry to analyse the samples may account for the difference in incidence of aneuploidy among patients with cervical intraepithelial neoplasia grade I and atypia induced by human papilloma virus infection. Our study showed that by using an objective criterion for aneuploidy together with both static and flow cytometry the sensitivity of detecting aneuploidy can be considerably increased. Our results indicate the practical advantage of using a fast image analysis system to achieve a rapid and useful result.

These findings accord with those of a prospective study of women with mild cervical atypia, in which $22 \%$ of cases progressed to cervical intraepithelial neoplasia grade III within 22 months ${ }^{7}$ and they support the view that mild cervical atypia is a true precursor of neoplasia.

This research was supported by a Medical Research Council special project grant to OANH, KCW, and FL. We thank Mr J Rackley and Mr K Keeler of Coulter Electronics Ltd, Luton, for their help with the flow cytometry.

\section{References}

1 Friedlander ML, Hedley DW, Taylor IW. Clinical and biological significance of aneuploidy in human tumours. $\mathcal{F}$ Clin Pathol 1984;37:961-74.

2 Fu YS, Reagan JW, Richart RM. Definition of precursors. Gymecol Oncol 1981;12:220-31.

3 McIndoe WA, McLean MR, Jones RW, Mullins PR. The invasive potential of carcinoma-in-situ of the cervix. Obstet Gynecol 1984;4:451-4.

4 Spriggs A, Boddington MM, Clarke CM. Carcinoma-in-situ of the cervix uteri: some cytogenetic observations. Lancet 1962;i:1383-4.

5 Jakobsen A, Kristensen PB, Poulsen HK. Flow cytometric classification of biopsy specimens from cervical intraepithelial neoplasia. Cytometry 1983;4:166-9.

6 Crum CP, Egawa K, Barron B, Fenoglio CM, Levine RU, Richart RM. Human papillomavirus infection (condyloma) of the cervix and cervical intraepithelial neoplasia: a histopathologic and statistical study. Gynecol Oncol 1983;1:88-94.

7 Campion MJ, McCance DJ, Cuzick J, Singer A. The progressive potential of mild cervical atypia: a prospective cytological, colposcopic and virological study. Lancet 1986;ii:237-40.

8 Ploem-Zaaijer JJ, Beyer-Boon ME, Leyte-Veldstra L, Ploem JS. Cytofluorometric and cytophotometric DNA measurements of cervical smears stained using the new bi color method. In: Pressman NJ, Wied GL, eds. The automation of cancer cytology and cell image analysis. Chicago: Pressman NJ, Wied GL, eds. The automation of cancer cytology and cell image

9 Buckley CH, Butler EB, Fox H. Cervical intraepithelial neoplasia. $\mathcal{f}$ Clin Pathol 1982;35:1-13. 10 Hedley DW, Friedlander ML, Taylor IW, Rugg CA, Musgrove EA. Method for analysis of cellular DNA content of paraffin embedded pathological material using flow cytometry. $\mathcal{J}$ Histochem Cytochem 1983;31:1333-5.

11 Watts KC, Husain OAN. Optimal use of the cationic polyelectrolyte poly-L-lysine in the preparation of cell monolayers for diagnostic cytopathology. F Clin Pathol 1984;37:829-31.

12 Tucker JH, Shippey JH. Basic performance tests on the Cervifip linear array prescreener. Analytical and Quantitative Cytology 1983;5:129-36.

13 Hughes RG, Neill WA, Norval M. Nuclear DNA analysis of koilocytotic and premalignant lesions of the uterine cervix. Br Med $\mathcal{F}$ 1987;294:267-9.

(Accepted 25 August 1987) 